放射性鉄による鈎虫症の鉄代謝に関する研究

第 2 編

鉤虫乳剂注射の鉄代謝飞及佂す影響飞ついて

（本論文要旨は第44回日本消化機病学会総会において発表した）

岡山大学医学部平木内科教室（主任：平木 潔教授）

副手上塚香

内容目次

第 1 章 緒 言

第 2 章 実験材料並びに実験方法

第 3 章 実験成績

第 1 節 実験に用いた家鬼の血液像

第 2 節 放射性鉄の血咏中に於ける時間的消

長

第 1 項 鈎虫乳剂注射家兔

第 2 項 実験的䨘血家鬼

第 3 節 放射性鉄の赤血球への移行

第 1 項 鈎虫乳剂注射家鬼

第 2 項 実験的頜血家鬼

\section{第1章 绪言}

鈎虫症貫血の成因として中毒説は出血説と並んて 古くから多くの人々によつて強調されて来た．上 野6)は鈎虫々体アルコールエキスを注射した動物の 骨髄に著しい造血障害像を認め，宮川等63) は実験 的鈎虫犬に脾腫を来し，骨咀特に赤血球系に再生機 能の障害がある事を見, 村田67) は鉤虫犬の血液を 注射した家兔に造血機能減退像を認め，何れむ中毒 生障害を重視した。高橋・阿南31）は家兔化鈎虫乳 剤を注射すると贫血を来すか，この䨘血は脾の存在 に於て発現するとしている，之等の事から鉤虫症貫 血発生に何等かの毒素が作用している事が考えられ るが，との毒素について更に追求したものに小森19), 浅越1，松本57)，江口・三好9）等がある，教室に於 ても早くから鈎虫毒菜の検索が行われ，北山前教 投18）笠原，佐久間，内藤，岡等の一連の実験的 研究から，鈎虫々体及び鉤虫症患者血清中に催貧血 生物質を含む事を確認され，人体に寄生した鉤虫は 何等加の機構により脂肪様物質を分泌し，之が人体

\author{
第 4 節 脿器鉄各分剽の放射性鉄 \\ 第 5 節 吸収並びに吸収された放射性鉄の䐽 \\ 器分布 \\ 第 1 項 鉤虫乳剂注射家兔 \\ 第 2 項 実験的貫血家鬼 \\ 第 6 節 蓇器鉄各分酤の鉄量 \\ 第 1 項 鉤虫乳剂注射家鬼 \\ 第 2 項 実験的貧血家鬼 \\ 第 4 章 総括並びに考按 \\ 第 5 章 結論
}

に吸収されて，更に他の中性脂肪に変つて催頜血作 用を発揮するとされた。 その後鉤虫毒素の作用は鈎 虫症の鉄代謝との関連のもとに究明がすすめられ， 教室米谷52) は家兔に鉤虫症血清を注射すると鉄が 網内系仰抑留され，眝蔵鉄が増加する事を㔉器の鉄 染色等によつて半定量的に証明し，鉤虫毒素による 動員障客を强調している，之に引続き教室中塚40) は，更に，鈎虫犬及び鉤虫症血清注射家兔の貯蔵鉄 を分䧿定暴して增加を認め，鉄の動員障害を確認し ている.

著者は第 1 編に於て鉤虫症に於ける鉄代謝につい て検索し，本症には鉄の吸収及び動員の障害があり， 之等が出血による鉄の体外損耗之相俟つて貫血を惹 起する。乙の際動員の障害に関しては勿論, 吸収障 害に関しても鈎虫毒素の影響が考えられる事を述べ たが, 验虫症の場合, 出血或は鉤虫寄生による腸壁 の機械的な損傷等が扣わつて，鉤虫毒素そのものの 作用はどの様なものか判然としにくい，従つて第 1 編之関連のもとに，鈎虫毒素そのものの鉄代謝に及 ぼす影響を究明しようと試みたのであるが，上記諸 
家の研究からも明かな様に，鈎虫毒素は虫体毒素と 患者血清中のものとの二者に別けられ，本編では先 つ鈎虫々体毒素の作用を究明すへく，鉤虫乳剂注射 家兔に放射性鉄 $\left(\mathrm{Fe}^{59}\right)$ を経口投与し，之の鉄代謝 の様相を追求した。

\section{第 2 実医材料並び実験方法} 実験動物

体重 $2.0 \sim 2.5 \mathrm{~kg}$ の白色雄性健康家兔を使用し た.

鉤虫乳剂

室温にて充分乾嬠した人及び犬の鉤虫を乳鉢にて 磨りつぶし，4隻に対し生理的食塩水 $1.0 \mathrm{cc}$ を加 え, $60^{\circ} \mathrm{C} 1$ 時間加温し, 水室に眝え, 使用に際し ては 1 分間 1000 迴転で遠心沈澱し，その軽獨した上 清液を用いた。

実験方法

上記鉤虫乳剂を体重每 $\mathrm{kg} 1.0 \mathrm{cc}$ を 1 日 1 回，連 続 1 週間皮下注射した家兔及び健康家兔に放射性鉄 を経口投与し，経時的に心被穿刺を行つて採血し， 血䈋及び赤血球中の放射能を測定し，48時間後に生 体灌流を行つて，肝，脾，骨髄，及び十二指腸上部 の非へミン鉄を分割し，その放射能及び鉄量を測定 した.

経口投与した放射性鉄の調製法及び投与量，非へ ミン鉄の分舦測定法，放射能の测定法及び実験数值 の算出法は第 1 編に記载したむのと同じであり，毎 回無処置健康家兔についてむ実験を行つて対照之し た. 尚，生体灌流は Copp \& Greenberg81) が行つ た方法に準じて生理的食塩水を用いて行つた。

更に上記実験と比較考察する意味で，ベンゾール を体重毎 $\mathrm{kg} 0.3 \mathrm{cc} 1$ 日 1 回連続 30 日間注射した家 兔及び体重每 kg $5.0 \mathrm{cc}$ の瀉血を 1 日 1 回連続15回 行つた家鬼についても上記同様実験した。

\section{第 3 草 実 酫 成 繈}

第 1 第 実験汇用いた家鬼の血液像（第 1 表，第 2 表)

第 1 表 鉤虫釈剂注射家鬼の血液像

\begin{tabular}{|c|c|c|c|c|c|c|c|}
\hline & $\begin{array}{l}\text { 家 } \\
\text { 鬼 } \\
\text { 菓 }\end{array}$ & $\begin{array}{c}\text { 体 } \\
\text { 重 } \\
(\mathrm{kg})\end{array}$ & $\begin{array}{l}\text { 経 } \\
\text { 過 } \\
\text { 日 } \\
\text { 数 } \\
\end{array}$ & $\begin{array}{l}\text { 血枽 } \\
\text { 色量 } \\
\text { (\%) }\end{array}$ & $\begin{array}{l}\text { 赤血 } \\
\text { 球数 } \\
\left(10^{4}\right)\end{array}$ & $\begin{array}{l}\text { 網血 } \\
\text { 球 } \\
\text { 赤数 } \\
(\%)\end{array}$ & 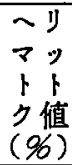 \\
\hline 煡 & No. 23 & 2.1 & & 90 & 612 & 15 & 45 \\
\hline 康 & No. 24 & 2.0 & & 93 & 557 & 7 & 43 \\
\hline 鬼 & No. 29 & 2.2 & & 96 & 585 & 14 & 44 \\
\hline
\end{tabular}

\begin{tabular}{|c|c|c|c|c|c|c|c|}
\hline & No. 42 & 2.3 & $\begin{array}{l}\text { 前 } \\
7\end{array}$ & $\begin{array}{l}92 \\
84\end{array}$ & $\begin{array}{l}543 \\
475\end{array}$ & $\begin{array}{l}10 \\
24\end{array}$ & 39 \\
\hline 体家 & No. 43 & 2.2 & $\begin{array}{c}\text { 前 } \\
7\end{array}$ & $\begin{array}{l}90 \\
81\end{array}$ & $\begin{array}{l}605 \\
514\end{array}$ & $\begin{array}{l}12 \\
18\end{array}$ & 43 \\
\hline & No. 44 & 2.4 & $\begin{array}{l}\text { 前 } \\
7\end{array}$ & $\begin{array}{l}95 \\
87\end{array}$ & $\begin{array}{l}575 \\
495\end{array}$ & $\begin{array}{r}9 \\
16\end{array}$ & 42 \\
\hline & No. 14 & 2.2 & $\begin{array}{c}\text { 前 } \\
7\end{array}$ & $\begin{array}{l}88 \\
80\end{array}$ & $\begin{array}{l}592 \\
497\end{array}$ & $\begin{array}{l}18 \\
23\end{array}$ & 41 \\
\hline 作 & No. 15 & 2.2 & $\begin{array}{c}\text { 前 } \\
7\end{array}$ & $\begin{array}{l}90 \\
84\end{array}$ & $\begin{array}{l}621 \\
523\end{array}$ & $\begin{array}{r}9 \\
17\end{array}$ & 42 \\
\hline & No. 41 & 2.4 & $\begin{array}{c}\text { 前 } \\
7\end{array}$ & $\begin{array}{l}94 \\
85\end{array}$ & $\begin{array}{l}575 \\
491\end{array}$ & $\begin{array}{l}11 \\
15\end{array}$ & 39 \\
\hline
\end{tabular}

第 2 表 実験的實血家鬼の血湤像

\begin{tabular}{|c|c|c|c|c|c|c|c|}
\hline & $\begin{array}{l}\text { 家 } \\
\text { 鬼 } \\
\text { 莒 }\end{array}$ & $\begin{array}{c}\text { 体 } \\
\text { 重 } \\
(\mathrm{kg})\end{array}$ & $\begin{array}{l}\text { 経 } \\
\text { 過 } \\
\text { 数 }\end{array}$ & $\begin{array}{l}\text { 血美 } \\
\text { 色量 } \\
\text { (\%) }\end{array}$ & $\begin{array}{c}\text { 赤球 } \\
\text { 血数 } \\
\left(10^{4}\right)\end{array}$ & $\begin{array}{l}\text { 網血 } \\
\text { 球 } \\
\text { 赤数 } \\
(\% 0)\end{array}$ & 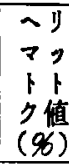 \\
\hline \multirow{3}{*}{$\begin{array}{l}\text { 健 } \\
\text { 康 } \\
\text { 毚 }\end{array}$} & No. 26 & 2.0 & & 89 & 585 & 11 & 45 \\
\hline & No. 27 & 2.1 & & 95 & 604 & 8 & 46 \\
\hline & No. 8 & 1.8 & & 82 & 480 & 13 & 44 \\
\hline \multirow{9}{*}{$\begin{array}{l}\text { 慢 } \\
\text { 性 } \\
\text { 簤 } \\
\text { 血 } \\
\text { 魏 }\end{array}$} & & 2.2 & 前 & 97 & 617 & 8 & 45 \\
\hline & No. 3 & & 15 & 56 & 406 & 195 & \\
\hline & & 2.0 & 20 & 70 & 586 & 58 & 35 \\
\hline & & 2.5 & 前 & 92 & 585 & 12 & \\
\hline & No. 39 & & 15 & 48 & 387 & 176 & \\
\hline & & 1.9 & 20 & 52 & 412 & 144 & 31 \\
\hline & & 2.1 & 前 & 95 & 605 & 15 & \\
\hline & No. 28 & & 15 & 49 & 375 & 159 & \\
\hline & & 1.9 & 20 & 47 & 325 & 226 & 21 \\
\hline \multirow{9}{*}{ 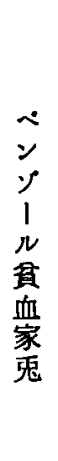 } & & 2.0 & 前 & 97 & 651 & 15 & \\
\hline & No. 1 & & 10 & 82 & 454 & 27 & \\
\hline & & 1.6 & 30 & 71 & 370 & 5 & 34 \\
\hline & & 2.3 & 前 & 94 & 619 & 16 & \\
\hline & No. 4 & & 10 & 74 & 437 & 28 & \\
\hline & & 2.0 & 30 & 67 & 385 & 2 & 35 \\
\hline & & 2.5 & 前 & 93 & 554 & 11 & \\
\hline & No. 38 & & 10 & 82 & 465 & 18 & \\
\hline & & 2.1 & 30 & 65 & 332 & 5 & 31 \\
\hline
\end{tabular}

第 2 節 放射性鉄の血整中に於ける時間的 消長

経口投与後 $1 ， 2 ， 4 ， 6 ， 12 ， 24$ ，48時間目に血繁 $1.0 \mathrm{cc}$ 中の放射能を測定した。 
第 1 項 鈎虫乳剂注射家兔（第 3 表，第 1 図） 無処置健康家鬼, 人鈎虫乳剂注射家鬼及び犬鉤虫 乳剂注射家鬼の 3 群について実験した。その結果最

第 3 表 故射性鉄の血浆中飞於ける時間的消長 （鈎虫乳剂注射家兔） count $/ 10 \mathrm{~min}$. /cc.

\begin{tabular}{|c|c|c|c|c|c|c|c|c|}
\hline & $\begin{array}{l}\text { 家鬼 } \\
\text { 番号 }\end{array}$ & 1 & 2 & 4 & 6 & 12 & 24 & 48 \\
\hline 健 & No. 23 & 86 & 304 & 372 & 158 & 36 & 88 & 128 \\
\hline 康 & No. 24 & 298 & 516 & 278 & 218 & 28 & 104 & 66 \\
\hline 鬼 & No. 29 & 298 & 386 & 400 & 320 & 54 & 96 & 68 \\
\hline$\hat{\lambda}_{\text {注 }}$ & No. 42 & 239 & 327 & 455 & 216 & 79 & 69 & 26 \\
\hline 虫家 & No. $4 ?$ & 256 & 452 & 224 & 194 & 104 & 144 & 147 \\
\hline 婇永 & No. 44 & 135 & 287 & 397 & 147 & 71 & 5 & 54 \\
\hline 犬注 & No. 14 & 174 & 264 & 596 & 260 & 56 & 56 & 36 \\
\hline 虫塮 & No. 15 & 316 & 406 & 330 & 184 & 92 & 80 & 32 \\
\hline 乳菟 & No. 41 & 251 & 339 & 425 & 234 & 87 & 24 & 28 \\
\hline
\end{tabular}

第 1 図故射性鉄の血整中に於ける時間的俏長 （鈎虫乳㓮注射家兔）

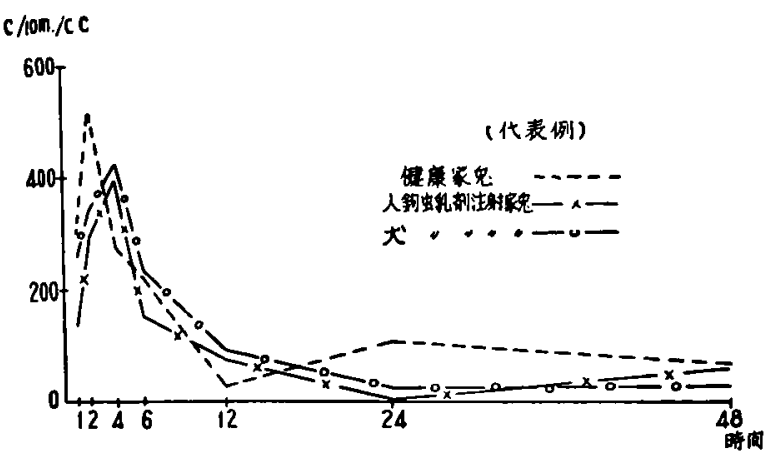

高の値を示すのは三者共に 2 又は 4 㭙間目であり， 最高値を比較するに，対照と大差を認めない，血鼎 中からの消失む各例共略同悌で，12㭙間目迄比較的 急速に減少し，以後漸減するものと48時間迄略同し 值を示すすのとがある，即ち，血洯中に於ける態度 は対照と大差を認めない.

第 2 項 実験的貫血家兔（第 4 表，第 2 図） 無処置健康家蚛，ベンソール䨘血家兔及び㴼血貫 血家兔の 3 群について夷験した．その結果最高值を 示すのは三者共 1 時間目で，ベンソール貫血の 1 例 のみが 4 時間目となつている，最高值を比較すると， 慢性潐血貫血家鬼は著明に高值で，健康家鬼の約15 倍である.ベンソール貫血家兔は健康家兔よりやや 低值である，慢性滇血䨘血家兔は最高值を示した後 は急敬に隇少し，4〜12時間で最低值となり，以
第 4 表 放射性鉄の血漿中飞於ける時間的消長 （実驗的貧血家息） count/10min. /c. c.

\begin{tabular}{|c|c|c|c|c|c|c|c|c|}
\hline & 家嵬 & 1 & 2 & 4 & 6 & 12 & 24 & 48 \\
\hline $\begin{array}{l}\text { 健 } \\
\text { 康 } \\
\text { 家 } \\
\text { 兔 }\end{array}$ & $\begin{array}{l}\text { No. } 26 \\
\text { No. } 27 \\
\text { No. } 8\end{array}$ & $\begin{array}{l}258 \\
312 \\
302\end{array}$ & $\begin{array}{l}199 \\
270 \\
192\end{array}$ & $\begin{array}{r}38 \\
138 \\
66\end{array}$ & $\begin{array}{r}108 \\
32 \\
122\end{array}$ & $\begin{array}{l}54 \\
31 \\
0\end{array}$ & $\begin{array}{r}80 \\
40 \\
145\end{array}$ & $\begin{array}{c}0 \\
30 \\
154\end{array}$ \\
\hline 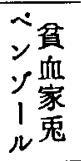 & $\begin{array}{l}\text { No. } 11 \\
\text { No. } 4 \\
\text { No. } 38\end{array}$ & $\begin{array}{r}54 \\
176 \\
201\end{array}$ & $\begin{array}{l}142 \\
160 \\
175\end{array}$ & $\begin{array}{c}208 \\
160 \\
168\end{array}$ & $\begin{array}{r}116 \\
120 \\
96\end{array}$ & $\begin{array}{r}132 \\
64 \\
48\end{array}$ & $\begin{array}{l}18 \\
0 \\
0\end{array}$ & $\begin{array}{l}27 \\
12\end{array}$ \\
\hline $\begin{array}{l}\text { 慢貫 } \\
\text { 性血家 } \\
\text { 血兔 }\end{array}$ & $\begin{array}{l}\text { No. } 3 \\
\text { No. } 39 \\
\text { No. } 28\end{array}$ & 2166 & 816 & $\begin{array}{l}120 \\
889 \\
274 \\
\end{array}$ & $\begin{array}{l}340 \\
322 \\
252\end{array}$ & $\begin{array}{l}464 \\
112 \\
115\end{array}$ & $\begin{array}{r}1008 \\
84 \\
472\end{array}$ & $\begin{array}{l}984 \\
235 \\
378\end{array}$ \\
\hline
\end{tabular}

第 2 図放射性鉄の血然中に於ける時間的消長 （実駼的贯血家鬼）

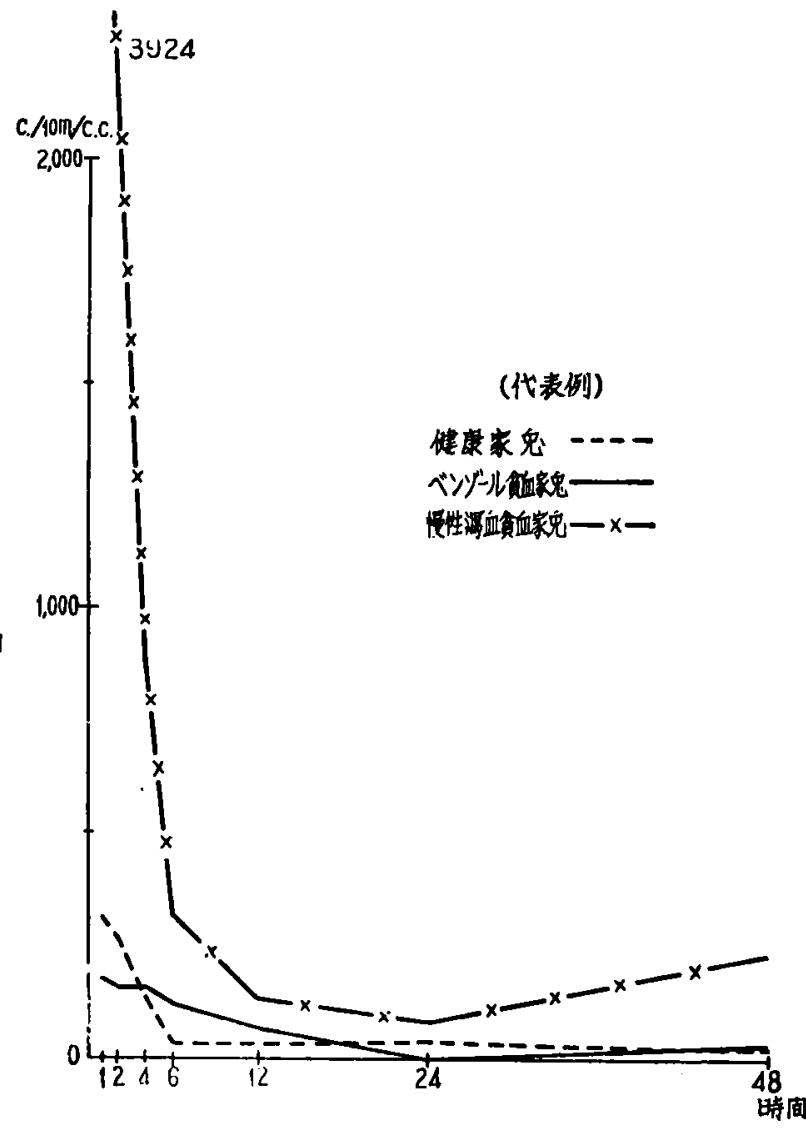

後略同じ值を保つあのと，24特間目から再び可成な 高值を示して48特間任至るすのがある，健隶家鬼及 びベンゾール貫血家鬼小漸减してゆくが，ベンゾー ル賓血家兔つ曲線は平泹て，減少が稍々楥慢である。

第 3 節 放的性铁つ赤血球への移行 経口段与後 $4,6,12,24$ ，48.侍間目に赤血球 $1.0 \mathrm{cc} の$ 
放射能を測定した。

第 1 項 鉤虫乳剂注射家兔（第 5 表. 第 3 図） 各例共に 4 時間目加ら僅加移行しはじめ，以後

第 5 表 故射性鉄の赤血球への移行（钧虫 乳刘注家鬼） count/10min. /c. c.

\begin{tabular}{|c|c|c|c|c|c|c|}
\hline & 家 & 4 & 6 & 12 & 24 & 48 \\
\hline \multirow{3}{*}{$\begin{array}{l}\text { 揵 } \\
\text { 康 } \\
\text { 家 } \\
\text { 忽 }\end{array}$} & No. 23 & 32 & 140 & 74 & 390 & 2570 \\
\hline & No. 24 & 62 & 52 & 150 & 682 & 1918 \\
\hline & No. 29 & 86 & 186 & 475 & 1230 & 2060 \\
\hline \multirow{3}{*}{ 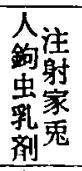 } & No. 42 & 12 & 104 & 274 & 895 & 1354 \\
\hline & No. 43 & 0 & 172 & 182 & 1094 & 1186 \\
\hline & No. 44 & 28 & 66 & 129 & 541 & 1018 \\
\hline \multirow{3}{*}{$\begin{array}{l}\text { 犬 } \\
\text { 銁注 } \\
\text { 虫糘 } \\
\text { 乳鬼 }\end{array}$} & No. 14 & 14 & 134 & 302 & 900 & 1138 \\
\hline & No. 15 & 56 & 130 & 200 & 1516 & 1244 \\
\hline & No. 41 & 23 & 119 & 196 & 775 & 996 \\
\hline
\end{tabular}

第 3 図放射性鉄の赤血球への移行（鈎虫 乳剂注射家兔）（代表例）

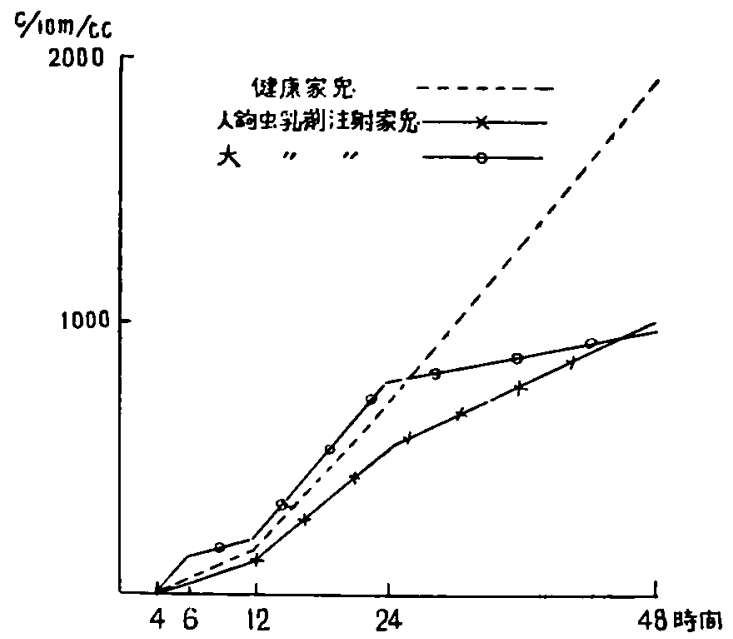

次第に増加するが48時間目には差がはつきり現われ， 乳剂注射家兔は対照の $1 / 2 \sim 2 / 3$ の值を示す.

第 2 項 実験的負血家兔（第 6 表，第 4 図）

健康家兔は6 時間目から移行しはじめ，以後渐增 する. 慢性滨負血家兔では 4 時間目に既に可成高值 を示し，以後急激に増加して，48時間後には健捸家 鬼の約25倍に達する，ベンゾール貫血家兔では極め て低值で，1 例では殆ど移行せず，他の 2 例む24封 間目加僅加に移行しはじめ，48特間で健康犬の約 1/4 に過ぎない.
第 6 流 放射性鉄の赤血球への移行（実駼 的盆血家兔） count $/ 10 \mathrm{~min}$. $/$ c.c.

\begin{tabular}{|c|c|c|c|c|c|c|}
\hline & 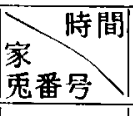 & 4 & 6 & 12 & 24 & 48 \\
\hline \multirow{3}{*}{$\begin{array}{l}\text { 㯬 } \\
\text { 康 } \\
\text { 冢 } \\
\text { 鬼 }\end{array}$} & No. 26 & 0 & 114 & 84 & 278 & 1280 \\
\hline & No. 27 & 10 & 68 & 188 & 776 & 1926 \\
\hline & No. 8 & 18 & 144 & 208 & 1044 & 2538 \\
\hline \multirow{3}{*}{ 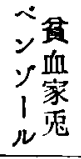 } & No. 11 & 0 & 64 & 96 & 26 & 24 \\
\hline & No. 4 & 38 & 31 & 40 & 160 & 576 \\
\hline & No. 38 & 0 & 27 & 58 & 212 & 456 \\
\hline \multirow{3}{*}{$\begin{array}{l}\text { 慢金 } \\
\text { 性血 } \\
\text { 渞家 } \\
\text { 血鬼 }\end{array}$} & No. 3 & 8336 & 12332 & 14848 & 37216 & 50088 \\
\hline & No. 39 & 5244 & 9476 & 11985 & 31738 & 45322 \\
\hline & No. 28 & 9918 & 13322 & 15723 & 32048 & 54272 \\
\hline
\end{tabular}

第 4 図放射性鉄の赤血球への移行（実蜸的貫 血家鬼）

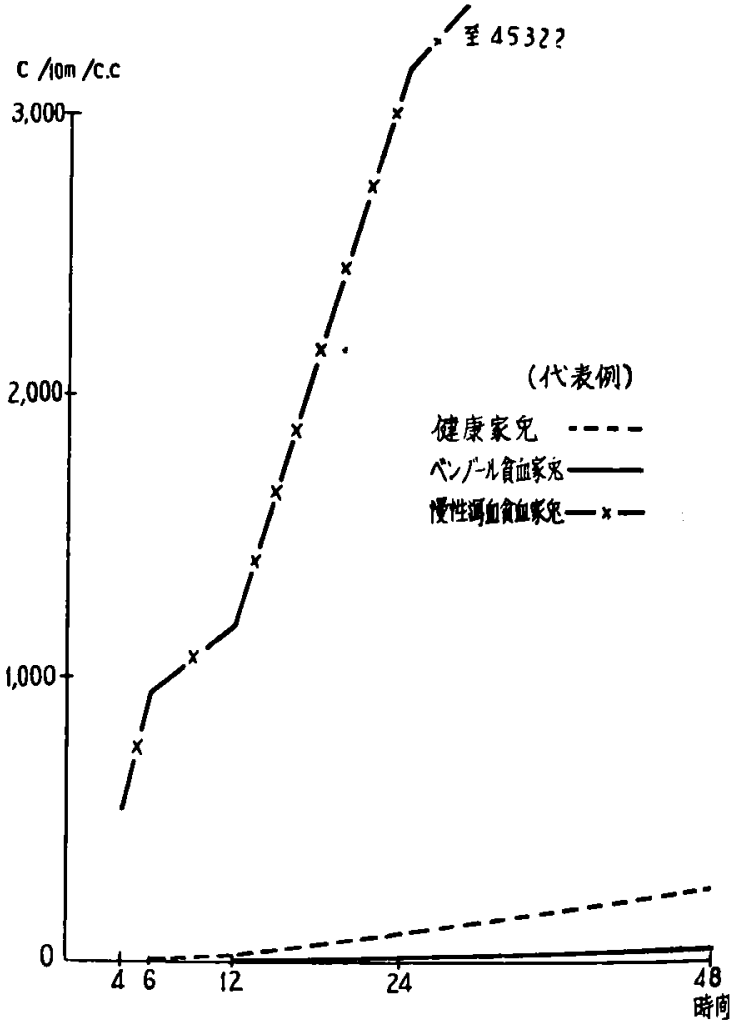

第 4 節 搭器鉄各分副の放射性鉄 鉤虫乳剂注射家兔の䑏器鉄各分剂の放射性鉄は第 7 表の通りで，各 3 例の平均值を相互に比較すると 第 5 図の如くである，人及び犬の鈎虫乳剤注射家鬼 は共に同じ傾问を示している. 即ち䏦, 脾の $\mathrm{PI}$, PII K於て対照より多く，骨鄙及び十二指渴の $P_{I}$, PII では対照と大差を認めない，PIII，SIIIは一般 


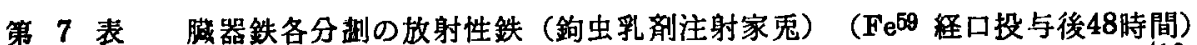

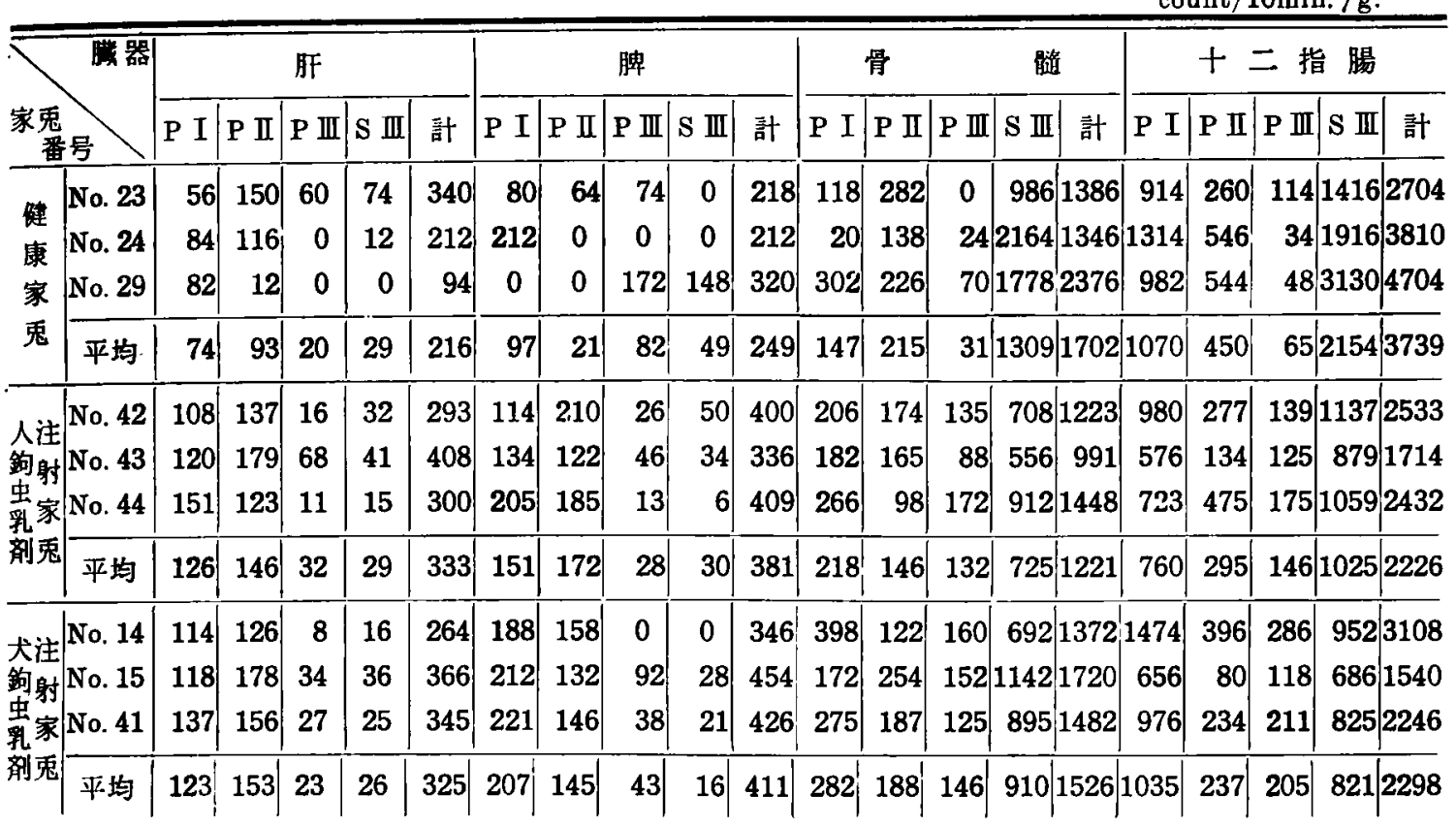

第 5 图淢器铁各分割の放射性鉄(钧虫乳剂注射家兔) (3㗅平圴)

健康家鬼

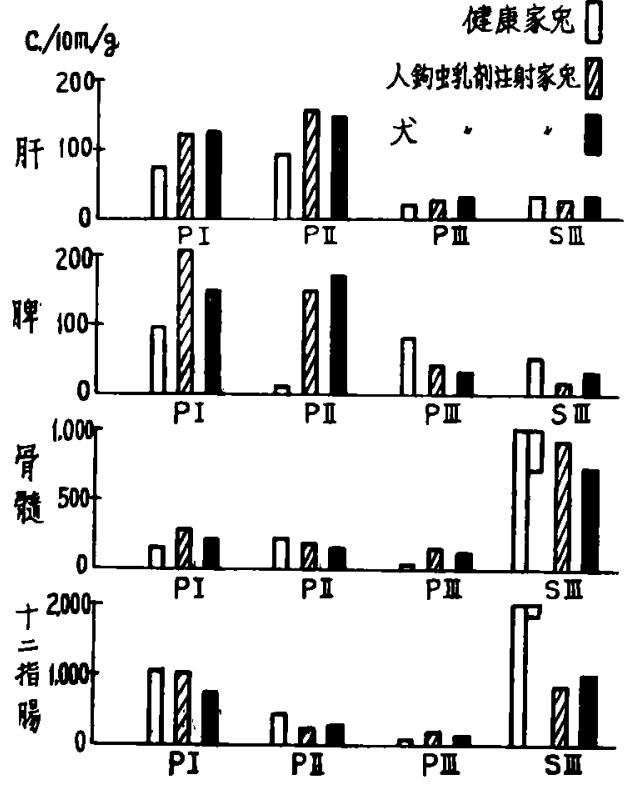

に低值で何れも大差ないが，骨髄及び十二指腸の

PIIIは三者共に可成高值を示している.

\section{第 5 節 吸収並びに吸収された放射性鉄の 瀻器分布}

第 1 項 鉤虫乳剂注射家兔

経口投与後48時間目の赤血球, 肝, 脾, 骨髄の全 放射性鉄の投与量に対する百分率は第 8 表の如くで ある. 赤血球, 肝, 脾, 骨鹃有の放射性鉄の投与量に 対する百分率の和は吸収率に近い值を示すと考えら れ，以後吸収率と云う語はこの和を意味する，吸収 率を相互に比較すると第 6 四の如くて，対照健康家 兔は1.37〜1.86\%で，乳剂注射家兔は人鉤虫を用い た場合も犬鈳虫を用いた場合も略同じで，対照より 低値で約1.096である.

更に吸収された放射性鉄が赤血球，肝，脾，骨髄 の各々にどの様な比率で分布しているかを知る為に， 上記吸収率を $100 \%$ として百分率で表わすと第 9 表

第 8 表 赤血球及び肝，蜰，骨桻の放射性鉄の投与量に対する百分率（\%)

（鉤虫乳剂注射家兔）（Fe $\mathrm{e}^{59}$ 経口投与後48時間）

\begin{tabular}{|c|c|c|c|c|c|c|c|c|c|c|c|}
\hline \multirow[b]{2}{*}{ 蚟 量 } & \multirow[b]{2}{*}{ 器 } & \multirow[b]{2}{*}{ 家鬼番号 } & \multicolumn{3}{|c|}{ 健 康 家 鬼 } & \multicolumn{3}{|c|}{ 人跔虫乳剂注射家息 } & \multicolumn{3}{|c|}{ 犬鉤虫乳剂注射家鬼 } \\
\hline & & & No. 23 & No. 24 & No. 29 & No. 42 & No. 43 & No. 44 & No. 14 & No. 15 & No. 41 \\
\hline 赤 & 血 & 球 & 1.16 & 0.83 & 0.91 & 0.53 & 0.51 & 0.43 & 0.47 & 0.52 & 0.39 \\
\hline & 肝 & & 0.18 & 0.09 & 0.03 & 0.11 & 0.17 & 0.13 & 0.12 & 0.15 & 0.15 \\
\hline & 脾 & & 0.002 & 0.001 & 0.002 & 0.004 & 0.004 & 0.005 & 0.004 & 0.006 & 0.004 \\
\hline 骨 & & 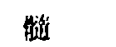 & 0.46 & 0.45 & 0.92 & 0.41 & 0.33 & 0.48 & 0.46 & 0.57 & 0.49 \\
\hline & 計 & & 1.80 & 1.37 & 1.86 & 1.05 & 1.01 & 1.05 & 1.05 & 1.24 & 1.03 \\
\hline
\end{tabular}


第 6 圀吸収事（鉤虫乳剂注射家鬼）

（Fe $\mathrm{e}^{59}$ 経口投与後48時間）

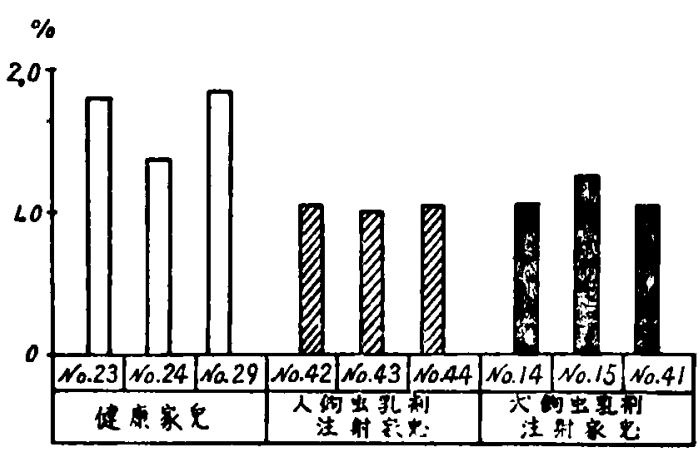

の如くて，人鉤虫，犬鉤虫乳斉何れの場合も同じ傾 向で，対照に比して赤血球に移行する率が低く，䀒 脾, 骨䯣に認められる率が高い傾向にある.

第 2 項 実験的費血家兔

経口投与後48時間目の赤血球，肝，脾，骨賄の全 放射性鉄の投与量に対する百分率は第10表の如くて， 吸収率を相互に比較したのが第 7 図である. 健康家 鬼は 1.36〜2.37\%でベンゾール貧血家鬼はその約 1/2，慢性鴧血實血家鬼はその10～15倍で，著明な 差がある.

更に上記同様にして，吸収された鉄の縢器分布を

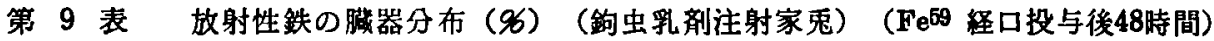

\begin{tabular}{|c|c|c|c|c|c|c|c|c|c|c|c|}
\hline \multirow[b]{2}{*}{ 䑏器 } & & \multirow[b]{2}{*}{ 家鬼番号 } & \multicolumn{3}{|c|}{ 趾 康家 鬼 } & \multicolumn{3}{|c|}{ 人鈎虫乳戍注射家鬼 } & \multicolumn{3}{|c|}{ 犬鈎虫秏剂注射家鬼 } \\
\hline & & & No. 23 & No. 24 & No. 29 & No. 42 & No. 43 & No. 44 & No. 14 & No. 15 & No. 41 \\
\hline 赤 & 血 & 球 & 64.4 & 60.6 & 49.0 & 50.5 & 51.0 & 41.0 & 44.8 & 41.0 & 37.9 \\
\hline & 肝 & & 10.0 & 6.6 & 1.6 & 10.5 & 16.8 & 12.4 & 11.4 & 12.1 & 14.6 \\
\hline & 脾 & & 0.1 & 0.1 & 0.1 & 0.4 & 0.4 & 0.5 & 0.4 & 0.5 & 0.4 \\
\hline 骨 & & 慥 & 25.6 & 32.8 & 49.5 & 39.0 & 32.7 & 45.7 & 43.8 & 46.0 & 47.6 \\
\hline & 計 & & 100.0 & 100.0 & 100.0 & 100.0 & 100.0 & 100.0 & 100.0 & 100.0 & 100.0 \\
\hline
\end{tabular}

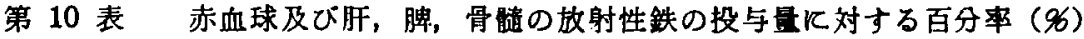

（実験的貧血家兔）（Fe $\mathrm{e}^{59}$ 経口投与後48封間）

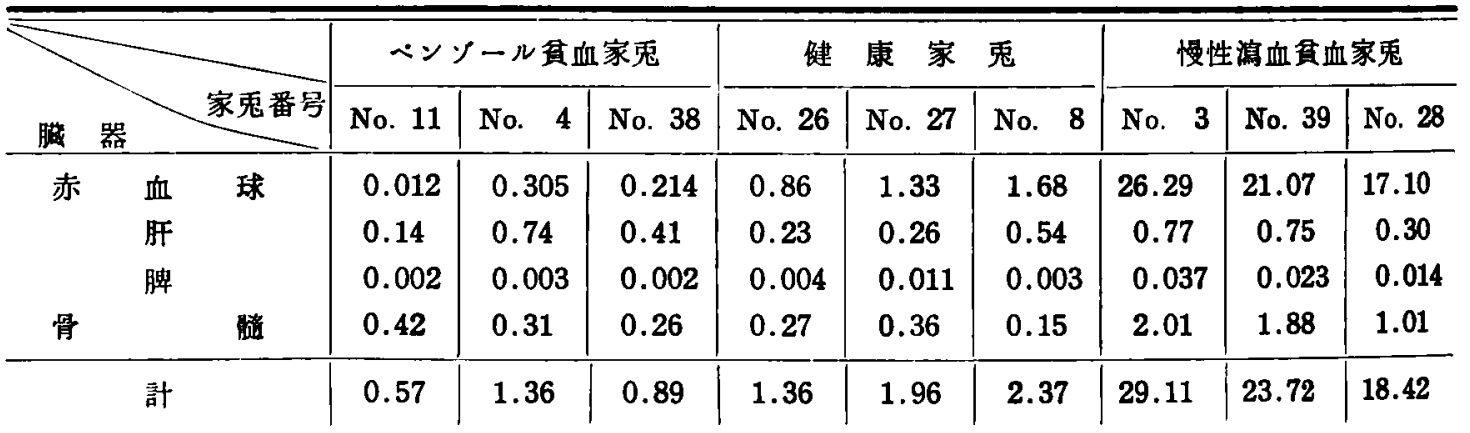

第 7 图吸収率（実敇的貫血家兔） ( $\mathrm{Fe}^{59}$ 経口投与後48時間)

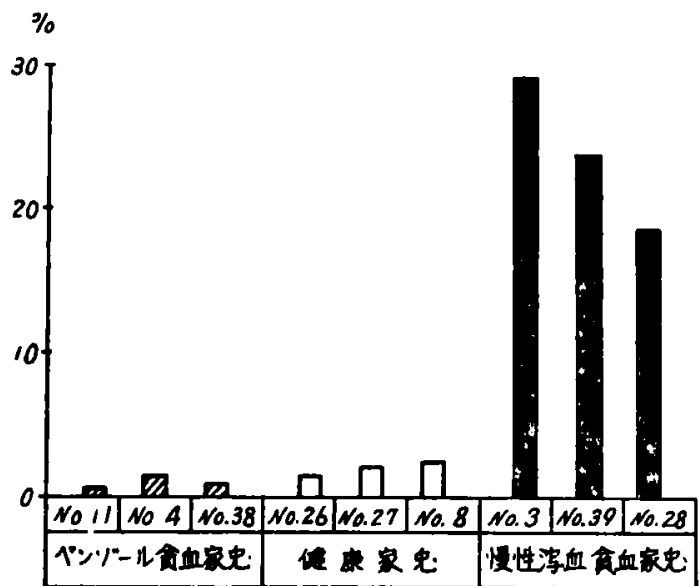

見ると第11表の如くで，ベンゾール盆血家鬼で対 照に比して，赤血球に移行する戠が低く，肝，骨喠 に分布する率が高い，特に肝には約50\%が認められ る，慢性湍血貣血家鬼では之と全く逆保，赤血球に 移行する率が極めて高く(約90\%)，肝，脾，骨邻 には栐めて低率である。

\section{第 6 筑 腈器鉄各分到の鉄量}

第 1 項 鉤虫乳剂注射家兔 第12表の通りで，各 3 例平均值を相互に比校する と第 8 困つ如くである. 即ち人及び犬钧虫乳剂住射 家鬼共同じ傾向て，各哓器各分㖶共対照に比して 増加の傾向が見られる。 


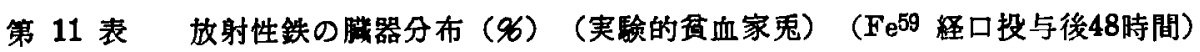

\begin{tabular}{|c|c|c|c|c|c|c|c|c|c|c|c|}
\hline & \multirow[b]{2}{*}{ 器 } & \multirow[b]{2}{*}{ 家鬼番号 } & \multicolumn{3}{|c|}{ ヘンンソール貫血家鞂 } & \multicolumn{3}{|c|}{ 健 康 家 鬼 } & \multicolumn{3}{|c|}{ 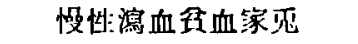 } \\
\hline & & & No. 11 & No. 4 & No. 38 & No. 26 & No. 27 & No. 8 & No. 3 & No. 39 & No. 28 \\
\hline \multirow[t]{3}{*}{ 赤 } & & 球 & 2.1 & 22.4 & 24.2 & 63.3 & 67.8 & 71.0 & 90.5 & 89.0 & 93.0 \\
\hline & & 肝 & 24.6 & 54.4 & 46.2 & 16.9 & 13.5 & 22.8 & 2.7 & 3.2 & 1.6 \\
\hline & & 脾 & 0.4 & 0.2 & 0.2 & 0.3 & 0.6 & 0.1 & 0.1 & 0.1 & 0.1 \\
\hline \multirow[t]{2}{*}{ 骨 } & & 做 & 73.7 & 22.8 & 29.2 & 19.7 & 18.4 & 6.3 & 6.9 & 7.9 & 5.6 \\
\hline & & 計 & 100.0 & 100.0 & 100.0 & 100.0 & 100.0 & 100.0 & 100.0 & 100.0 & 100.0 \\
\hline
\end{tabular}

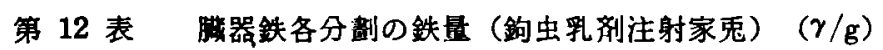

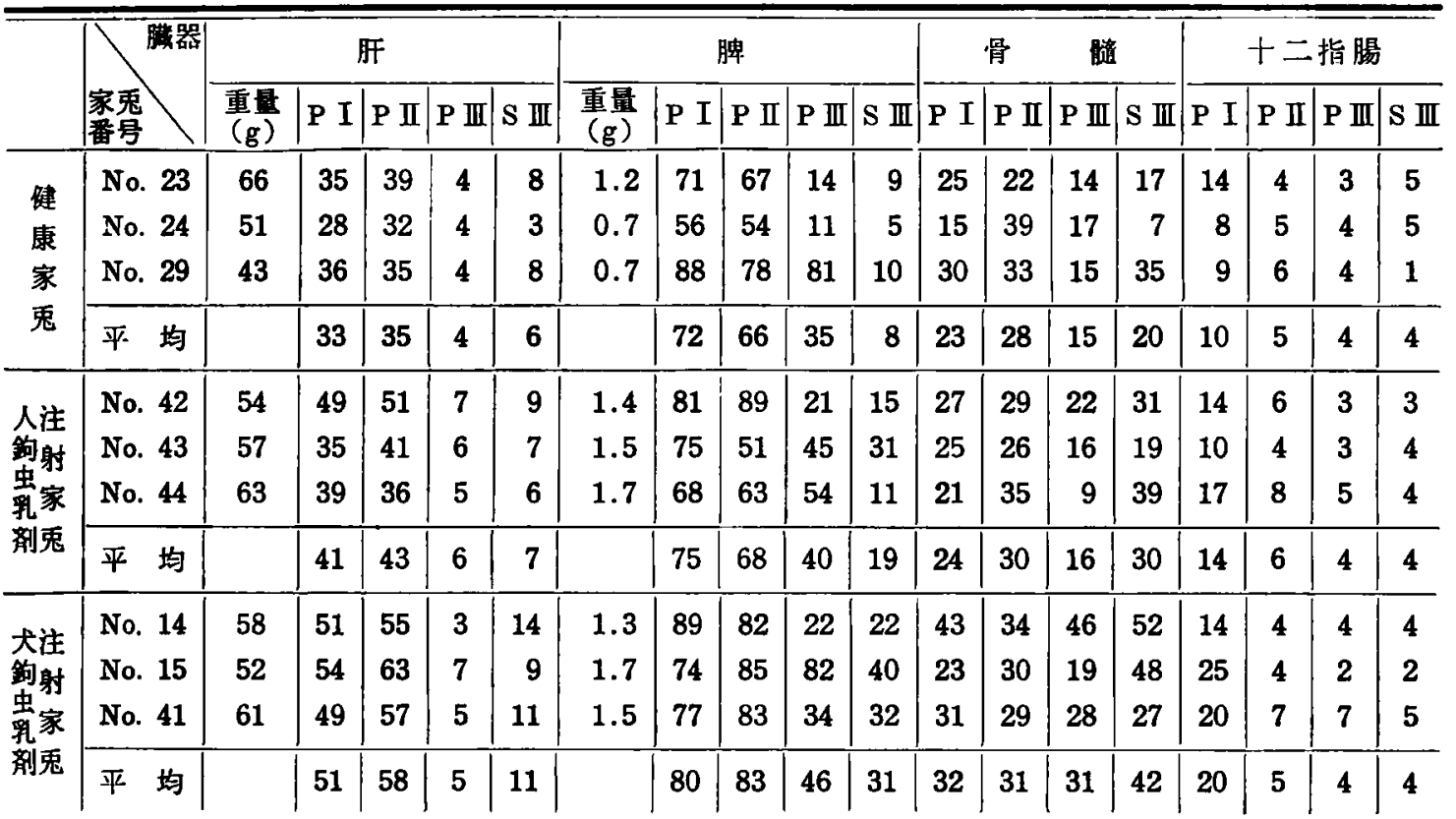

第 8 図脿器鉄各分劃の鉄量（鈎虫乳剂注射家鬼）

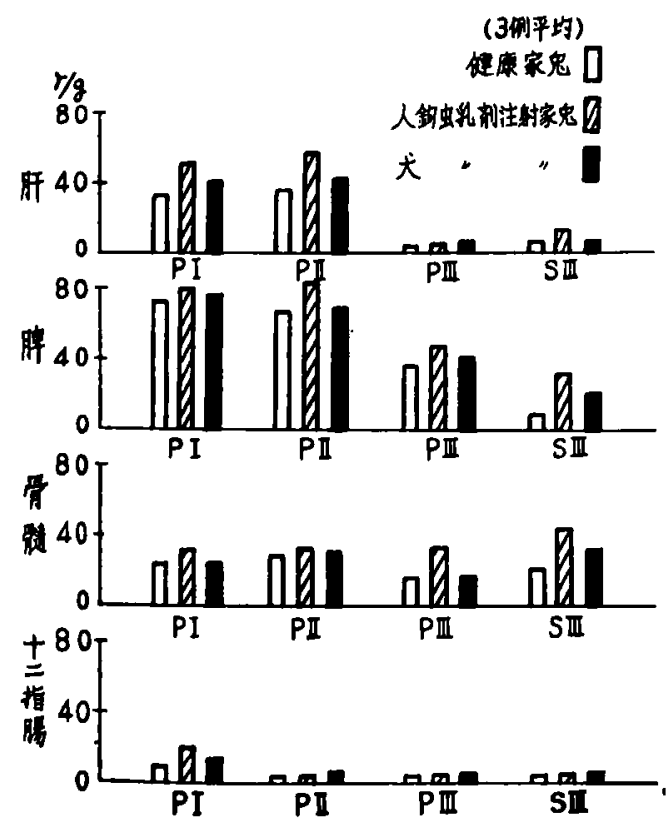

第 9 困脿器鉄各分猎の鉄量（実験的貫血家兔）

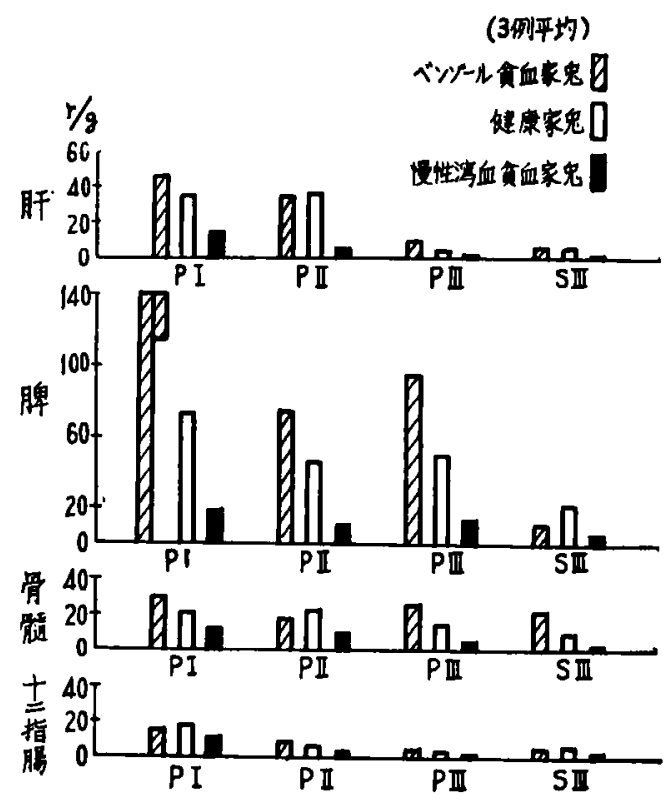




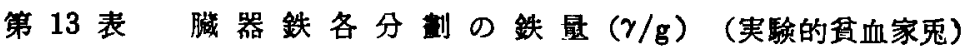

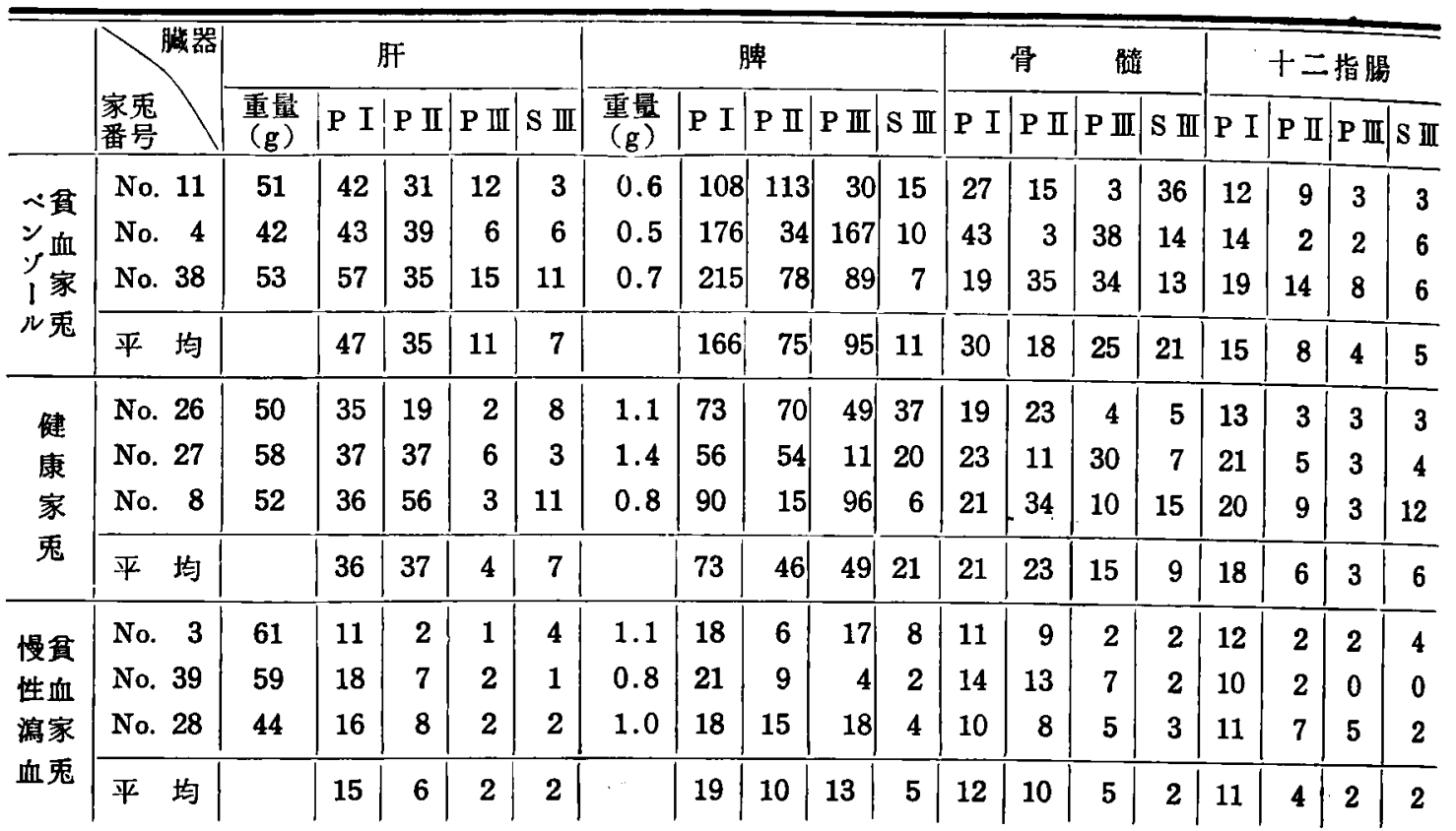

第 2 項 実験的負血家鬼

第13表の通りで，各 3 例平均値を相互に比較する と第 9 図の如くである. ヘンゾール貫血家兔では対 照に比して，肝，骨髄，及び十二指腸では殆ど差を 認めないが，脾では可成増加し，就中 $P_{I}, P_{I I I}$ に 於て増加が著しい，慢性演血負血家鬼は各臟器各分 劃共著减しているが, 特に肝, 脾のPI，P $\mathrm{P}$ に於け る減少が著しい.

\section{第4章総括並ひに考按}

以上の実験成績を総括すると次の如くである.

\section{1）鈎虫㗭剂注射家鬼}

人鈎虫，犬鈎虫を用いた場合共に同じ傾向を示し た。即ち対照に比して，吸収率は可成低く，吸収さ れた鉄は，赤血球に移行する率が低く，肝，脾，骨 䯣に分布する率が高い傾向が認められた. 又䑏器鉄 各分猎放射性鉄は肝，脾の $\mathrm{PI}_{1}, \mathrm{P}_{I I}$ に於て対照よ

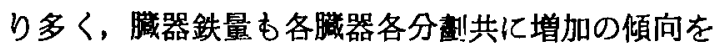
示した.

\section{2）実験的貝血家鬼}

ベンゾール貫血家鬼の吸收率は対照より可成低值 で，吸収された鉄は赫血球に移行する率が低く，肝， 骨䯣に䯩率である，滕器鉄各分劃の鉄量は対照に比 しで脾の Pr，PIII に著明な増加を示し，他は大差 を認めない，慢性㴼血恧血家鬼では之と逆に，吸収 率は極めて高く，吸収された鉄の大部分は赫血球に 移行し, 肝, 脾, 骨榷には極めて低率に認められる

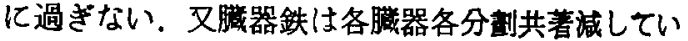
石.

扰て，鉤虫乳剂又は鈎虫抽出液を注射した動物に

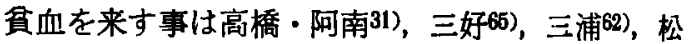
本58), 笠原 14 )等の実験の示す処であつて, 著者の実験 に於てす血色素量で約10\%,赤血球数で約100万の減 少を来した.との䆩血について高橋・阿南31)は胖の存 在に於て発現するとし, 江口・三好9）は網内系機能が 関与していると述べ，三好66）は鈎虫の食塩水エキス 注射では貧血を来すが，蜔虫，蟯虫エキスでは貝血

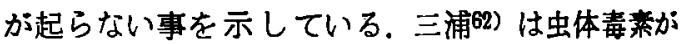
肝，脾，骨䯣に作用して，之等組織の変調を来して 貝血を起すと考えている. 更にこの虫体毒亲につい て北山前教授16)，松本57) 等の研究があるが，北山 前教授は，腸管に寄生した鈎虫は脂肪様の物質を分 泌し，之か人体に吸収され，更に他の中性脂肪に変 り，县髄からの赤血球の遊出を挪制するとされた， その後教室に於ては更に研索を進め，藤田60)は鈎 虫症患者血清は骨䯣に直接作用して動脈系を収粳せ しぬ，赤血球を静脈洞内に抑留 (Knochenmarksperre）せしぬる事を明かにすると共に，藤井49) はその場合の骨鲔内血流状態をサイアヂン曲線によ り测定し，その遅延を証明した。

而して鉤虫症䨘血の本热究明に腙しては，鉄代謝 面からの研索が如何に重要であるかは論荐俟たない 処であつて，鉤虫症の鉄代謝に関する研究は第 1 瘄 に述ベた如く種々行われているが，鉤虫ふ体毒莱の 
鉄代謝に及にす影響については皆無に近く，特に系 統的に行われた研究は見当らない. 先つ鈎虫症に 於りる鉄の吸収に関する研究を振返つてみるに，福 島・千田46)，教室中塚40)(還元鉄経口投与訬験の 吸収曲線が低い事から, 又岩城4) は鈎虫犬に経口投 与した故射性鉄の血摮中に於ける最高值の比較及び 赤血球への出現率から，吸收障害があると述へてい るのであるが，之等は鉤虫症に鉄の吸収障害がある 事を示しているのであつて，ての吸收障害が何によ つて惹起されるかは不明である。

著者は第 1 編に於て，鉤虫症の吸収障害に関して 鈎虫毒素の作用が考えられる事を述へたが，本編の 钩虫乳剂注射家兔の吸収率は明汃対照より低值て あり，之によつて鈎虫々体毒素か吸收障害に関与し ている事を確認し得た訳である. 尚この際経口投与 した放射性鉄の血漿中に於ける最高值は対照と大差 なく，吸收率に於て明かな差を認めた事は，吸収の 良否判定に際して，血清鉄の変動，即古吸収曲線の 比校のみでは不充分な場合があり，著者の用いた方 法がより適確である事を物語つていると云えよう.

次に，鉤虫乳剂注射家鬼に投与した鉄の淢器分布 については僅かに中尾36)の実験が見られるのみで， 鈎虫乳剂注射家兔で賓血を来した例では，静注した 放射性鉄は肝，脾に多く入る点が目立つていると述 へてているに過ぎない，著者は吸収，䑏器分布及び利 用等を同一個体で相互関連のもとに研索したのであ るが，吸収された鉄は赤血球に移行する率が低く， 䏦, 脾, 骨骮有に分布する率が高い傾向が認奻られ,

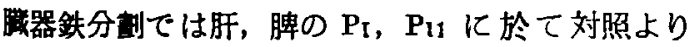

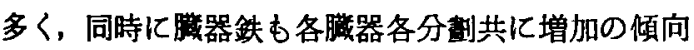
が見られた。この事は，吸収された鉄は勿論，既存 の体内鉄をも含めて，鉄詝蔵器の主として $P_{I}, P_{I 1}$ に入つた鉄は動員され難い事を示しているものと思 われる．乙れ等の成績は第 1 編の鉤虫犬に見られた あのと同し傾向であつて，銁虫症に於ける鉄の吸収 及ひ動員の障害に関して鉤虫々体毒䒺か重要な役割 を演している事を物語つている。

更に，上記実験と比較する急味で同様に実験した ベンゾール貧血及び慢性㴼血貧血家兔について考察 しょう.ベンゾールが家鬼の造血哓器を障害, 破壊 する事は Selling125) の発表以来数多くの研究によ つて示され, 長谷川43), 中村41), 富塚33) 等は慢性 ベンゾール中毒により再生不良性負的に似た像を萑 起し, 同時に脾, 所その他の網内系の変性をむ続発 する事を認めている，又教室水田73)に上喥，べ
ンゾール貫血家兔の血清鉄には著明な変䭒なく，臟 器各分劃の鉄量は肝では正常又は稍々減少し, 脾, 骨髄の $P_{1} ， P_{11}$ は增加が著明で，腎では各分剖共 に增加し，網内系機能は障害される. 即ちベンゾー ルによる赤血琭破壊，造血機能低下により鉄が肝， 脾に多呈に蓄皘されるが，て机等䐵器により充分処 理されないで一部は留より排泄される，又網内系機 能の低下による缄器鉄の減少む推察出来ると述へて いる，著者の実験であ荿器鉄に関しては水田と類似 の傾向を示している。

次に，吸収及び吸収された鉄の歲器分布を見る に，造血機能の低下，及び詝蔵鉄の増加がある場合 鉄の吸収が減退する事は実験的に或は臨休的に Pirzio122)，Bothwell77) の示す処であつて, ベンゾ 一ル貧血では網内系が障害さ机る為に眝蔵器が鉄を 保持する能力が低下して，眝蔵鉄の增加は著明では ないが，吸収の减退を示した著者の成績は当然と考 えられる. 又僅か吸収された鉄む造血機能低下の 為に赤血球に移行する率が低く, 徒つて受野的に眝 蔵器に多く分布されるむのと思われる。銁虫乳剂注 射家兔及び第 1 編に於ける鉤虫犬であ之と類似の脿 器分布を示したが，鉤虫症の場合はベンゾール䨘血 の場合とは全く異つた意味をるつている，即ち鈎虫 症に於て血清鉄が減少する事は諸家の示す処であり，

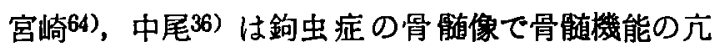
進を見, 教室木村18)は Sideroblast の研究加ら血 色素生成に利用される鉄の久乏状態侄ある事を証明 している. 更に教室柚本71)は鉤虫症患者の骨昜培 養及び骨骮江患者血清を添加した培養成縝功，鉤 虫毒素は直接骨隺を障害するのではない事を示して いる. 又剑虫乳剂注射侮して䁈血と共に血清鉄が 减少する事は教室喜多島15)の実験に見られる。以 上はすへて鉤虫毒素が直接骨髄を障害するのでない 事を直接又は間接に示すむのであつて，鉤虫症に於 ける臟器分布は造血機能低下による受動的なすので なく，眝蔵器からの動員障害によるものと考えざる を得ない。

慢性渲血䆩血に於ける血清鉄の減少は Heil-

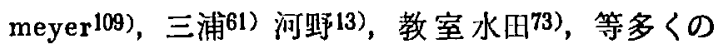
報告があり，臟器鉄が著明に減少する事はShoden126)， 山下69）,Hoskins 113)，教室水田73) 等の研究に見ら 机る. 又 Hahn101), Austoni \& Greenberg ${ }^{74)}$, Copp \& Greenberg81822)，中尾36）等は鉄欠之状隹にある 動物に於ける鉄の吸収は正常動物に比して著明に六 進し，吸収された鉄は大部分が血色素生成に利用さ 
れ，町蔵器にけ殆ど認められなくなる事を，放射性 鉄を用いた実験で示している，著者の慢性㴦血費血

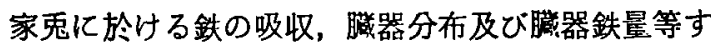
へて上記諸家の成績と一致し，失血による鉄欠之の 為に血色素生成の素材である鉄に対する需要が著明 に六進している事を示している，慢性滨血寅血は 失血による鉄の絶体的欠乏状態にあるが，鉤虫症で は出血及び吸収障害の為に鉄の欠之を来すと共に， 鉄の動員障害によつて貯蔵鉄は比較的増加の傾向に あり乍ら，更に強い鉄の欠乏状態を招来するのであ つて，両者を比較する時誠に興味深いものがある。

\section{第 5 章 結論}

鈎虫症賓血の発現に関して鉤虫々体毒素が如何な る役割を演じているかを知る目的で，鈎虫乳剂注射 家兔に放射性鉄を経口投与し，その鉄代謝の様相を 追求した。
鈎虫乳剂注射家兔では対照に比して，吸収率が低 く，吸収された鉄の臟器分布をるるに，赤血球への 移行は低率で，肝，脾，骨骮使分布する率が高い㥀 向にある．同時に臓器鉄は増加の傾向を示した：以 上より鉤虫症貧血発現の要因たる鉄の吸収及び動員 障害に関して鉤虫々体毒素が重要な役割を演してい る事を知つた。

尚ベンゾール䨘血家兔及び慢性瀉血䨘血家鬼につ いても同様に実験して，上記成績と此較検討した。

稿を終るに当り終始御蒩篤なる御指迋と御校閲を 賜つた恩師平木教授飞深甚の謝意を表すると共飞大 藤助教授の御校閲並びそ木村博士の御援助を深謝す る.

（文献は巻尾に一括記栈する）

\title{
Studies on the Iron Metabolism in Hookworm Disease by means of Radioactive Iron $\left(\mathrm{Fe}^{59}\right)$ Administration
}

\section{Part 2. Effects of the Injection of Hookworm Emulsion on the Iron Metabolism}

\author{
By \\ Kaoru Uetsuka \\ Department of Internal Medicine Okayama University Medical School \\ (Director: Prof. Kiyoshi Hiraki)
}

After the oral administration of radioactive iron, $\mathrm{Fe}^{59}$, to the rabbits injected with emulsion of hookworms from human or dogs and to normal rabbits (control), the author investigated the effects of toxin of the hook worm body on the iron metabolism.

As the results the rabbits injected with hookworm emulsion show the lower rate of absorption by the digestive tract and up-take of the absorbed $\mathrm{Fe}^{69}$ to erythrocytes when compared with the control, and $\mathrm{Fe}^{59}$ tends to be distributed more in the liver, spleen and bone marrow. At the same time the iron contents in organs show a tendency of an increase as compared with the control.

From these findings it appears that toxin in the body of hookworm plays an important role in the disturbances of the absorption and mobilization of iron. In addition, the author conducted similar experiments on the rabbits with chronic anemia by blood depletion and on the rabbits with benzol anemia and compared their results. 